\title{
How to keep your staff healthy in the educational sector?
}

\author{
Mihaela Rotaru, ${ }^{1, *}$ \\ ${ }^{1}$ Lucian Blaga University of Sibiu, Faculty of Engineering, Emil Cioran street no.4, Sibiu, Romania
}

\begin{abstract}
The purpose of the paper is to identify risks and challenges for alternative forms of work during online classes for teaching personnel. Musculoskeletal disorders (MSD) affect the body's bones, muscles, joints, ligaments/tendons, and nerves. Musculoskeletal health risk in the educational sector should be taken into consideration to ensure the safety and healthy employees, especially when online classes require a physical inactivity and a prolonged sitting in front of the computer. MSD management requires an integrated approach integrating wellbeing with a focus on prevention, recognizing physical, social and emotional influences and early intervention. Workplace wellness has been a valuable tool and technique for maximizing employee health and workplace efficiency.
\end{abstract}

\section{Introduction}

In March 2020 all teaching activities were transferred online because of the pandemic global situation $[1,2,3]$ so this changed the work process and increased the sedentary risk factors associated that are corelated with musculoskeletal disorders (MSDs). Work processes have changed, and new technologies have reduced virus exposure, but organizations have viewed their own responsibility for what happens at work from home as limited. Many mandated legal risk assessments that guide preventive activities to reduce physical exposure do not consider the health concerns of stress, MSDs, and fatigue, and most of them rarely consider the human aspects for different people. Owing to a lack of literature on occupational health promotion and intervention assessment of measures implemented in various workplaces, there is a lack of understanding about what to evaluate and how to assess it.

\section{Legal requirements on risk prevention and Methods}

Actual legislation on health and safety is set by proposals from the European Commission that are voted upon by European Union members. The EU Directive is constitutionally binding on each member state and is adopted into each member state's national legislation. The primary function of the EU is to harmonize legal criteria. Guidance on risk assessment at work Directive 89/391/EEC describes how the employers should based the strategies for identification of hazards and control the risk on the participation and consultation of their employees.

\footnotetext{
${ }^{*}$ Corresponding author: mihaela.rotaru@ulbsibiu.ro
} 
Provisions on workload, ergonomic and psychosocial risk that we can mention are:

OSH directive 90/270/EEC - display screen equipment

OSH directive 90/26/EEC - manual handling of load

OSH directive 2003/88/EC - working time

OSH directive 2000/78/EC - equal treatment - combats the discrimination at workplace and specifies the accommodation that are impose for people with disabilities

OSH directive 89/655/EEC - work equipment - specifies the suitability of work equipment

OSH directive 89/654/EEC - workplace requirements - specifies the minimum requirements for workplace

OSH directive 89/391/EEC - OSH framework directive

The paper research followed an actual state research approach, looking at literature review on MSD in educational sector, proposals shared by EU National Focal Points and OSHA proposals for MSD to corroborate and identify different factors corelated with MSD in educational sector. To point the gaps that are not sufficiently investigated, it was necessary to investigate successful good practices implemented in different EU countries and also to do 15, one-to-one interviews with colleagues from different universities in Romania and USA.

\section{Discussion}

Musculoskeletal disorders (MSD) has been recognized as a common occupational problem in the teaching profession [4,5] however, most of the studies refer to physical activities associated with teaching activities [6,7].

MSDs are a category of inflammatory and degenerative diseases that involve the muscles, tendons, joints, ligaments, peripheral nerves, and the blood vessels that protect them. They are the leading cause of extreme long-term pain and injury, affecting hundreds of millions of people all over the world [12]. MSDs encompass a wide variety of illnesses, from minor ailments to chronic illnesses.

Lockdown is a common buzzword these days, and people have been debating it since the restriction were taken into force because of COVID-19 pandemic situation. In reality, since March 2020, the authorities of state governments have imposed a state of emergency protocol to prevent citizens from leaving their homes, culminating in mass quarantines and stay-athome orders around the world. This situation contributed to a shift towards online education. This was the only other alternative to close classroom in schools, colleges and universities all around the world. While some physical activities (taking the stairs, moving in the classroom, short walks between classes on the recess) were done by teachers while they were teaching in front of their students in a classroom in online teaching, this was no longer possible.

Students and teachers all together spent over 8 hours per day in front of a screen in a sitting position. Although students could shift their positions more often when their video camera was turned off for the teacher, this option was not available. Teachers sat on a chair in their home in front of their laptops without concerns regarding the possibility of developing MSD because of the lack of ergonomic postures in front of the screens.

Leading causes of lower back pain (LBP) in teachers are related to awkward posture $[7,8]$. For over one year, excessive sitting while focusing on students' work and planning classes and inappropriate furniture are the main contributing factors to LBP development for teachers. A growing body of research has found significant connections between not just the physical demands of one's workplace, but also the psychosocial and systemic influences that affect workers' lives at work $[7,9,10]$. Both students and teachers experienced stress, anxiety, 
isolation, loneliness, fear, pressure while teaching-learning online. All these factors can affect the wellbeing of the persons and can be detrimental to their health [11].

In all interviews, teachers identified low back pain as the most frequent form of MSD. Shoulder, neck, knee, and wrist pain were less frequently identified as MSDs.

From the interviews resulted many physical risk factors that can be linked to MSD pathology, such as doing high-repetition activities (typing, mouse clicking, laptop pad pressing, static position (extended sitting) and having a rigid work posture (rigid, awkward posture), both of which improve physical loading on the joints and soft tissues, resulting in feeling pain and muscles tension. The magnitude of the injuries is determined by several factors, including the frequency, length, and seriousness of the physical damage.

It can also be added psychological risk factors like overhead labor, repetitive demands from administration (department, faculty, university level), and inadequate control of work habits to lead to the occurrences of stress. This is the negative reaction that people get when they are subjected to undue pressure or demands. Academic publishing pressures, accreditations, budgets (finances), emotional constraint, time pressure, health issues, selfimposed stressors, and relationships with colleagues, family and friends are all factors that can cause university teachers to become overwhelmed (figure 1).

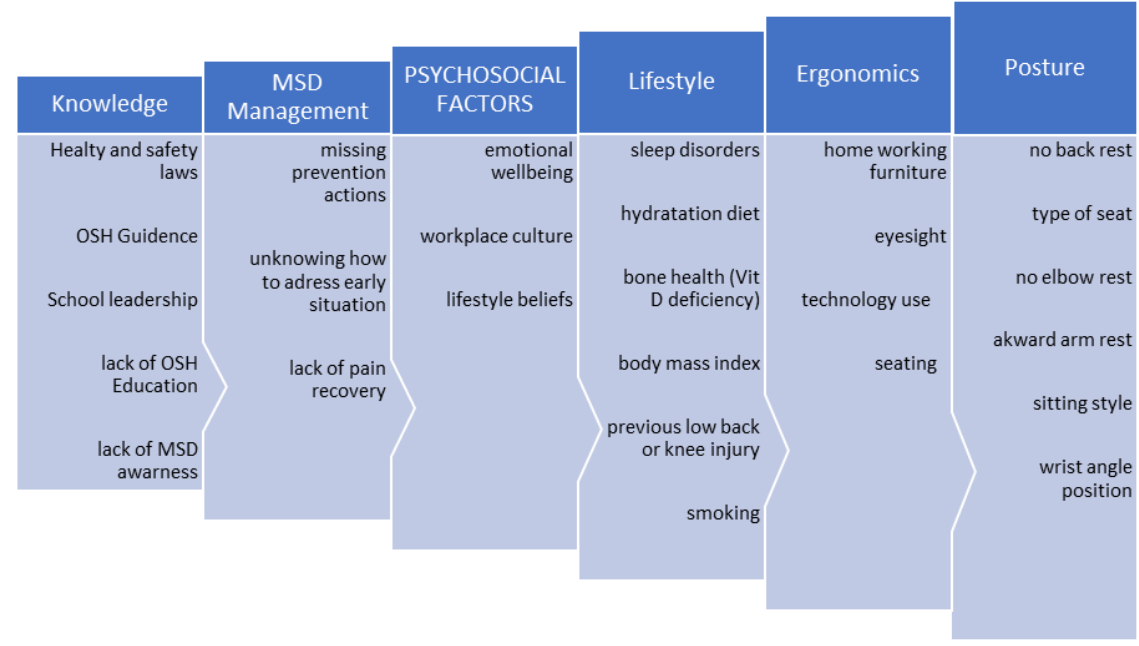

Fig. 1. Root cause analysis on MSDs.

While some stress is beneficial for the teacher activity, chronic stress leads to an increase in body weight, increase cortisol secretion and development of MSDs.

In Table 1 it is summarized the technical and organizational measures that can be taken by the employee and employer to combat the possible MSDs injuries.

The economic system is the primary lever by which every modern society operates on its resources; micro and macroeconomic decisions are founded on the criterion of economic performance/ utility. Can this be applied to the activity of ensuring workplace safety?

Table 1. Technical and organizational measures derived from MSDs risk assesment

\begin{tabular}{|c|l|}
\hline $\begin{array}{c}\text { Factors to } \\
\text { address }\end{array}$ & \multicolumn{1}{c|}{ Technical and organizational measure } \\
\hline Knowledge & $\begin{array}{l}\text { - the provisions of relevant laws; } \\
\text { - conformity with all adopted standards (occupational health and safety } \\
\text { policies); } \\
\text { - the ability to use occupational safety measures effectively. }\end{array}$ \\
\hline MSD management & Support for structural interventions includes: \\
\hline
\end{tabular}




\begin{tabular}{|c|l|}
\hline & $\begin{array}{l}\text {-maintaining an appropriate degree of expertise among personnel assigned } \\
\text { to use technical equipment; } \\
\text { - keeping a database of all activities aimed at ensuring correct use of } \\
\text { technical equipment. } \\
\text { - offering support to solve the early MSD injuries or MSD related pain. }\end{array}$ \\
\hline $\begin{array}{c}\text { Operational } \\
\text { measures for } \\
\text { wellbeing }\end{array}$ & $\begin{array}{l}\text { Wellbeing operational measures include: } \\
\text { - mindfulness classes to ensure a proper development of workplace culture, } \\
\text { - guidelines for the use of technical equipment and rules for support group, }\end{array}$ \\
\hline Lifestyle & $\begin{array}{l}\text { Lifestyle assessment: } \\
\text { - identifying performance-related and non-conformities of risk related } \\
\text { MSDs factors }\end{array}$ \\
\hline Ergonomics & $\begin{array}{l}\text { Improvement includes: } \\
\text { - identifying the need for changes in the use of technical equipment, } \\
\text { - an assessment of the effectiveness of improvement measures. }\end{array}$ \\
\hline Posture & $\begin{array}{l}\text { Posture improvement measure by physical exercises like stretching, exercise } \\
\text { in leisure time, regular short workouts, short walks and bending, pelvis } \\
\text { rocking, neck stretching, weight shifting }\end{array}$ \\
\hline
\end{tabular}

To solve the problem of workplace safety effectiveness, it is important to be able to determine a cost of protection, or vulnerability, which should be comparable to the costs of prevention (Table 2, Table 3 ).

The cost of security / non-security is actually the cost of accidents and occupational diseases avoided / produced, corresponding to the total value of all losses caused by the accident / disease [13]. In essence, stability denotes the lack of these occurrences. As a result, determining the expense of workplace injuries and occupational disorders is impossible if their effects are unknown and, indirectly, if these consequences cannot be quantified using objective, i.e. financial or economic indicators. Because of their diverse existence and the various planes on which they manifest, highlighting many of the effects of accidents and illnesses is especially daunting, but it is the only way to classify those that can be quantified. Accident and workplace disease costs should be used for more than just streamlining worker safety and health at the economic agent level.

Table 2. Individual costs resulted from accidents or work related illnesses [14]

\begin{tabular}{|c|l|l|}
\hline Variables & \multicolumn{1}{|c|}{ Description } & \multicolumn{1}{|c|}{ Costs } \\
\hline Health status & $\begin{array}{l}\text {-Hospitalization (hospitalization days) } \\
\text {-Other type of medical care, such as out- } \\
\text { of-hospital treatment, medications } \\
\text {-Permanent disability }\end{array}$ & $\begin{array}{l}\text {-Non-medical rehabilitation, } \\
\text {-Expenses for medical care that } \\
\text { are not reimbursed by the } \\
\text { insurance company or employer }\end{array}$ \\
\hline Life quality & $\begin{array}{l}\text {-Life expectancy, healthy life expectancy } \\
\text {-Quality lifespan } \\
\text {-Lifespan depending on disability }\end{array}$ & $\begin{array}{l}\text {-Th value of claims and } \\
\text { compensations }\end{array}$ \\
\hline $\begin{array}{c}\text { Pain and } \\
\text { suffering }\end{array}$ & $\begin{array}{l}\text {-For victims, but also for relatives and } \\
\text { friends }\end{array}$ & n/a \\
\hline $\begin{array}{c}\text { Loss of income } \\
\text { Expenses not } \\
\text { included in } \\
\text { insurance or } \\
\text { compensation }\end{array}$ & $\begin{array}{l}\text {-Loss of income from the first and } \\
\text { second job }\end{array}$ & $\begin{array}{l}\text {-Reduction of current income, loss } \\
\text { of salary } \\
\text { funeral costs }\end{array}$ \\
\hline
\end{tabular}

Table 3. University costs resulted from accidents or work-related illnesses[14].

\begin{tabular}{|c|c|c|}
\hline Variables & Description & Costs \\
\hline $\begin{array}{c}\text { Fatal accident, } \\
\text { death }\end{array}$ & Number of fatal accidents & $\begin{array}{c}\text { Amount of costs of subsequent activities, } \\
\text { fines and payments }\end{array}$ \\
\hline
\end{tabular}




\begin{tabular}{|c|c|l|}
\hline $\begin{array}{c}\text { Absenteeism or } \\
\text { sick leave }\end{array}$ & $\begin{array}{c}\text { Hours of work lost due to } \\
\text { absenteeism }\end{array}$ & $\begin{array}{l}\text { The sum of the costs of activities that } \\
\text { address the effects of lost labor hours, } \\
\text { such as replacement and educational } \\
\text { content losses; } \\
\text { the indirect effect is caused by sick leave } \\
\text { which reduces flexibility or the ability to } \\
\text { deal with unexpected situations }\end{array}$ \\
\hline $\begin{array}{c}\text { Early retirement } \\
\text { and disability }\end{array}$ & $\begin{array}{c}\text { Percentage or number of } \\
\text { people in a given period }\end{array}$ & $\begin{array}{l}\text { Amount of costs of activities generated by } \\
\text { disability or early retirement, fines, } \\
\text { compensation for victims }\end{array}$ \\
\hline $\begin{array}{c}\text { Non-medical } \\
\text { rehabilitation }\end{array}$ & $\begin{array}{c}\text { Money spent by the employer } \\
\text { to facilitate the return to work } \\
\text { (counseling, } \\
\text { adjustment of the job) }\end{array}$ & Invoices for counseling, etc. \\
\hline $\begin{array}{c}\text { Management of } \\
\text { absences due to } \\
\text { illness, injuries, } \\
\text { etc. }\end{array}$ & $\begin{array}{c}\text { Administrative activities to be } \\
\text { carried out by the company in } \\
\text { connection with sick leave }\end{array}$ & Total salaries for time spent at work \\
\hline $\begin{array}{c}\text { Other, non-health } \\
\text { costs (eg } \\
\text { investigations, } \\
\text { time management, } \\
\text { external costs) }\end{array}$ & $\begin{array}{c}\text { Time and money spent on } \\
\text { injury investigation, job } \\
\text { evaluation (which causes } \\
\text { accidents or illness) }\end{array}$ & Total salaries for time spent at work \\
\hline Opportunity costs & Loss of competitiveness & $\begin{array}{l}\text { Value of future projects lost because of } \\
\text { poor rating }\end{array}$ \\
\hline
\end{tabular}

Any institutional interventions must be well organized and must include management personnel, academic and administrative staff involved in their execution.

Measures must be tracked and reviewed on an ongoing basis to ensure that solutions are both up to date and meet evolving criteria.

\section{Conclusions}

Critical steps to increase MSD prevention are prioritization and resource allocation. Because of discrepancies in infrastructure and procedures, a single solution cannot be recommended. To ensure that occupational safety helps improve organizations' ability to perform their tasks it is necessary to create guidelines and implement technical measures as well.

A more consistent approach to assessment is needed. The continued emphasis on risk management must be questioned, and a prevention pathway, as mandated by law, must be used more rigorously. In the field of occupational safety and health, the priority is shifting from a focus on safety to one that recognizes the relevance of health problems. One of the goals of this research was to increase awareness of the long-term effects of MSDs, including the possibility of injury later in life. These consequences remain poorly known but inspection and compliance can be powerful tools for MSD prevention. Ergonomics knowledge and awareness must become a common tool shared among teaching personnel.

The need for work design implementation instead of simulating prevention of MSDs on papers it is mandatory. The necessity of understating the human and financial costs must become a priority.

Usable and effective data collection resources should be developed to allow organizational level assessment. This will provide assistance and direction to accomplish long-term strategy and prevention tool implementation and not only a formal accomplishment of legal requirements. 
Ergonomics expertise should be kept up to date and adequate for those who are responsible for implementing ergonomic knowledge in the workplace.

\section{Acknowledgement}

This paper has been funded by means of the project "SafeEngine-Blended Learning through Innovative Tools for Sustainable and Safety Engineering and Social Inclusion", Grant Number 2020-1-RO01KA203-080085.

\section{References}

1. https://www.who.int/emergencies/diseases/novel-coronavirus-2019/question-andanswers-hub/q-a-detail/coronavirus-disease-covid-19-schools [Accessed September 2020]

2. Ministerul Educatiei si Cercetarii - cabinet secretar de stat nr 217/GP/01.04.2020

3. https://www.ulbsibiu.ro/wp-content/uploads/documents/ca/2020/HCA-nr.-09-din11.03.2020.pdf [accessed March 2020]

4. https://osha.europa.eu/publications/factsheets/45 [accessed September 2020]

5. P. N. Erick, D. R. Smith, Ind Health, 53(4): 385-386 July (2015)

6. N. P. Vaghela, S. K. Parekh, Natl J Physiol Pharm Pharmacol 8(2):197-201 (2018)

7. P.N. Erick, D.R. Smith, BMC Musculoskelet Disord 15, 359 https://doi.org/10.1186/1471-2474-15-359 (2014)

8. A.P. Atlas, R.G. Bondoc, R.A. Garrovillas, R.D. Lo, J. Recinto, K.J. Yu, PTRP, MSPT: Prevalence of low back pain among public high school teachers in the City of Manila. Philipp J Allied Health Sci., 2 (1): 34-40, (2007)

9. N.C. Korkmaz, U. Cavlak, E.A. Telci, Sci Res Essays, 6 (3): 649-657, (2011)

10. Y.M. Ng, P. Voo, I. Maakip,BMC Public Health 19, 234 https://doi.org/10.1186/s12889019-6553-3, (2019)

11. A.T. Tantawy, A. A. Rahman, M. A. Ameer, Korean J Pain., 30(2): 126-133, (2017)

12. J. O. Crawford, E.Giagloglou, A. Davis, R. Graveling,S. Copsey, A. Woolf, European Agency for Safety and Health at Work, Working with chronic MSDs - good practice advice [Online]. Available: https://osha.europa.eu/en/publications/working-chronicmsds-good-practice-advice/view (Accessed on March 2021)

13. P.M. Mircea, M.S. Balteanu, JSE, 5, 4, (2014) (Available online) http://www.energycie.ro/archives/2014/nr_4/v5-n4-7.pdf (Accessed on May 2021)

14. European Agency for Safety and Health at Work, J. Mossink, M. de Greef, Inventarul costurilor sociale şi economice ale accidentelor de muncă https://www.protectiamuncii.ro/pdfs/publicatii_agentie/Issue_207.pdf [Accessed April 2021] 